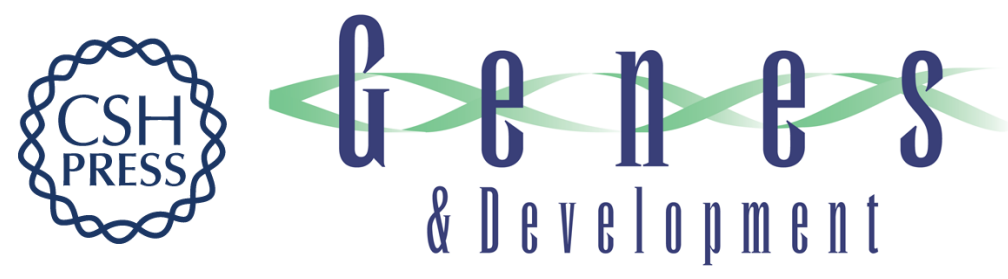

\title{
Replication factor-A from Saccharomyces cerevisiae is encoded by three essential genes coordinately expressed at $\mathrm{S}$ phase.
}

S J Brill and B Stillman

Genes Dev. 1991 5: 1589-1600

Access the most recent version at doi:10.1101/gad.5.9.1589

References This article cites 50 articles, 33 of which can be accessed free at:

http://genesdev.cshlp.org/content/5/9/1589.refs.html

Article cited in:

http://genesdev.cshlp.org/content/5/9/1589\#related-urls

Email alerting Receive free email alerts when new articles cite this article - sign up in the box at the service top right corner of the article or click here

To subscribe to Genes \& Development go to:

http://genesdev.cshlp.org/subscriptions 


\title{
Replication factor-A from Saccharomyces cerevisiae is encoded by three essential genes coordinately expressed at $S$ phase
}

\author{
Steven J. Brill and Bruce Stillman \\ Cold Spring Harbor Laboratory, Cold Spring Harbor, New York 11724 USA
}

Replication factor-A (RF-A) is a three-subunit protein complex originally purified from human cells as an essential component for SV40 DNA replication in vitro. We have previously identified a functionally homologous three-subunit protein complex from the yeast Saccharomyces cerevisiae. Here we report the cloning and characterization of the genes encoding RF-A from S. cerevisiae. Each of the three subunits is encoded by a single essential gene. Cells carrying null mutations in any of the three genes arrest as budded and multiply budded cells. All three genes are expressed in a cell-cycle-dependent manner; the mRNA for each subunit peaks at the $G_{1} / S$-phase boundary. A comparison of protein sequences indicates that the human $p 34$ subunit is $29 \%$ identical to the corresponding RFA2 gene product. However, expression of the human protein fails to rescue the rfa2::TRP1 disruption.

[Key Words: DNA replication; replication factor-A; S. cerevisiae; single-stranded DNA-binding protein]

Received June 10, 1991; revised version accepted July 6, 1991.

The study of eukaryotic DNA replication has relied heavily on the use of biochemistry to identify factors involved in the replication of eukaryotic chromosomes. For example, studies on the replication of SV40 DNA in vitro have been particularly useful in identifying human cell proteins required for viral DNA replication. However, the issue of whether these proteins function to replicate the chromosomal DNA of the cell cannot be addressed by using biochemistry alone; therefore, we have turned to the yeast Saccharomyces cerevisiae. The yeast system provides the genetics to address this question, as well as the only known chromosomal origins of DNA replication for future biochemical studies.

The SV40 system is based on the observation that plasmids containing the SV40 origin replicate in the presence of a protein extract from human cells and the viral initiator protein large $\mathrm{T}$ antigen ( $\mathrm{T}-\mathrm{Ag}$ ) ( $\mathrm{Li}$ and Kelly 1984, 1985; Stillman and Gluzman 1985; Wobbe et al. 1985). Human replication factors have been identified by biochemical fractionation of the cellular extract (Challberg and Kelly 1989; Stillman 1989; Hurwitz et al. 1990), and many aspects of the replication process can now be reconstituted by using purified proteins (Matsumoto et al. 1990; Tsurimoto et al. 1990; Weinberg et al. 1990). Because T-Ag performs multiple initiation functions, including origin-specific DNA-binding and DNA helicase activities, most of the human components are involved in the elongation stage of DNA replication [DNA polymerase $\alpha$ (Pol $\alpha)$, DNA polymerase $\delta$ (Pol $\delta$ ), proliferating cell nuclear antigen (PCNA), replication factor-A (RF-A), replication factor-C (RF-C), and DNA topoisomerases I and II] (Murakami et al. 1986; Prelich et al. 1987; Yang et al. 1987; Lee et al. 1989; Tsurimoto and Stillman 1989a; Weinberg and Kelly 1989; Melendy and Stillman 1991).

Human RF-A (also called RP-A and human SSB) is a single-stranded DNA (ssDNA)-binding protein complex composed of 70-, 34-, and 11-kD subunits (Wobbe et al. 1987; Fairman and Stillman 1988; Wold and Kelly 1988). RF-A is unique among the cellular proteins in that it has been shown to cooperate with T-Ag prior to the onset of DNA synthesis. Kinetically, preincubation of the template DNA with T-Ag, DNA topoisomerase I, and RF-A overcomes the lag in synthesis that is normally required for the establishment of a prepriming complex. The result of this preincubation is an extensively unwound DNA template (form U; Dean et al. 1987; Wold et al. 1987; Bullock et al. 1989; Tsurimoto et al. 1989) that can be primed by Polo. Subsequent elongation and switching of the polymerase complex to separate leading (Pols) and lagging $(\mathrm{Pol} \alpha)$ strand polymerases represents the elongation stage of DNA replication (Tsurimoto et al. 1990; Tsurimoto and Stillman 1991).

A role for RF-A in elongation has been inferred from its stimulatory effect on DNA polymerase activity with simple primer-template assays. At low levels of polymerase, RF-A stimulates Pol $\alpha$ activity four- to sixfold (Kenny et al. 1989; Tsurimoto and Stillman 1989b). In the presence of RF-C and PCNA, RF-A stimulates Polo activity 10-fold (Kenny et al. 1989; Tsurimoto and Stillman 1989b|. Escherichia coli single-stranded DNA-binding protein $(\mathrm{SSB})$ is unable to substitute for RF-A in some of these experiments, suggesting that the DNA polymerase 
stimulation is due to specific protein-protein interactions and not due simply to the effect of RF-A on the secondary structure of the template DNA. Indeed, monoclonal antibodies directed against individual subunits of RF-A inhibit these stimulatory effects (Kenny et al. 1990). RF-A also functions to inhibit reinitiation by Pol $\alpha$ on existing primers. As a result, Pol $\alpha$ synthesizes 300 - to 400-bp products typical of lagging strand products (Tsurimoto et al. 1990).

RF-A was identified in yeast extracts as a three-subunit protein complex consisting of $69-, 36-$, and $13-\mathrm{kD}$ subunits that cooperated with T-Ag and DNA topoisomerase I to unwind template DNA containing the SV40 origin of DNA replication. The yeast protein does not cross-react with antibodies raised against human RF$A$, and it does not substitute for the human protein in the complete SV40 DNA replication reaction (Brill and Stillman 1989). Like human RF-A, however, the yeast protein possesses a potent ssDNA-binding activity that is localized to the largest subunit (Brill and Stillman 1989; Wold et al. 1989; Kenny et al. 1990). In addition, the $36 / 34-\mathrm{kD}$ subunit of RF-A from both species is phosphorylated in a cell-cycle-dependent manner (Din et al. 1990). The phosporylated form of this protein appears in $S$ phase and persists until mitosis, at which time the protein becomes dephosphorylated. Phosphorylation of RF-A may function to regulate DNA replication; originunwinding experiments performed with $\mathrm{T}$-Ag and crude human cell extracts indicate that $G_{1}$ extracts have a lower specific unwinding activity than do extracts prepared from cells in the $S$ or $G_{2}$ phases of the cell cycle (Roberts and D'Urso 1988). $G_{1}$ extracts can be activated by a fraction, RF-S, that contains a kinase homologous to the p34 ${ }^{\text {cdc2 }}$ kinase (D'Urso et al. 1990). These results suggest a regulatory role for RF-A, potentially linking DNA replication to cell-cycle control mechanisms.

Although conclusive proof for a role for RF-A in chromosomal DNA replication is lacking, it is thought that RF-A may be the eukaryotic counterpart to such wellcharacterized SSBs as Escherichia coli SSB or T4 gene 32 protein. As a step toward obtaining genetic confirmation of the role of RF-A in chromosomal DNA replication, as well as its role in cell-cycle control, we have isolated and characterized the genes encoding RF-A from $S$. cerevisiae. All three subunits of RF-A, including the 36- and $13-\mathrm{kD}$ subunits, which apparently do not bind DNA, are required for viability. Cells lacking any of the three genes arrest as budded and multiply budded cells. mRNA for all three genes is expressed in a cell-cycle-dependent manner similar to genes known to be involved in DNA synthesis in S. cerevisiae. Finally, the RFA2 gene is unusual in that it contains an intron.

\section{Results}

\section{Cloning the genes encoding RF-A}

Tryptic peptides from each of the individual subunits of RF-A from $S$. cerevisiae were used to obtain internal amino acid sequence. Peptide sequences were used to design degenerate oligonucleotides as probes to obtain the genomic clones encoding each of the RF-A subunits (see Materials and methods). Figure 1 shows the genomic organization of the genes RFA1, RFA2, and RFA3 encoding the 69-, 36-, and 13-kD subunits, respectively. Protein-coding regions are boxed, and the direction of transcription is indicated by arrows. The chromosomal location of each of the RFA genes was obtained by physical mapping and is indicated in Figure 1. The position of the RFA genes with respect to known genetic markers was made possible by aligning the physical and genetic maps: $R F A 1$ maps to the CEN1-ADE1 interval on the right arm of chromosome I, RFA2 maps distal to RAD50 on the left arm of chromosome XIV, and RFA3 maps distal to $S R A 3$ on the left arm of chromosome $X$. There are no markers in these regions of the current genetic map that are likely to represent alleles of any of the RFA genes.

\section{Sequences of the RFA genes}

Nucleotide sequences were obtained for each of the genes encoding the subunits of RF-A. These DNA sequences are shown in Figure 2, along with the predicted translation products. Each translation product contains amino acid sequences (underlined) that are identical to those obtained by direct amino acid sequencing.

Figure 1. Genomic structure of the RFA1, $R F A 2$, and $R F A 3$ loci. Shown is a schematic representation of the three genes encoding subunits of RF-A. Horizontal lines represent flanking DNA; boxes represent protein-coding regions; arrows indicate the direction of transcription. An additional ORF (at least 332 amino acids) was found downstream of RFA2 and is indicated by the broken arrow. The downstream ORF showed no significant similarity to any protein in the data base. Also shown is the construction of disruption alleles and the chromosomal locations of the three genes as determined by physical mapping. Restriction site abbreviations: $(\mathrm{B}) \mathrm{BamHI}(\mathrm{C}) \mathrm{ClaI} ;(\mathrm{H})$ HindIII; (Hp) HpaI; (K) KpnI; (M) MluI; (Ms) MscI; (P) PstI; (Pv) PvuII; (R) EcoRI; (RV) EcoRV; (S) Sall; (Sc) SacI; (X) XbaI; (Xh) XhoI; $(\mathrm{Xm}) \mathrm{XmnI}$.
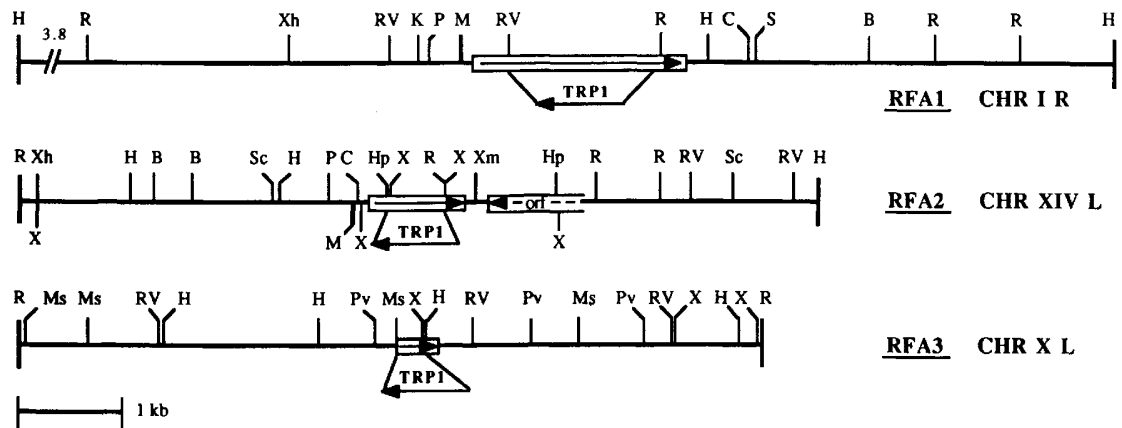
RFA1

CTGCAGTAGG CAAAGTTCCA GATAACACAC CACAAATACC CCATTTCCTT AGAAGTTTGA TGTGATCTAT GTCAAATACT AGCGGTGGCA TAAAAACCTC ATCGCCTTTT GCCGTTCTTT TTGCATATAT GTTAATAGCT ATGCGCGTAC CACCTTCTTC AGCCATATAC GAAAGGATCT ATGCTAATTG GGTGGATTTC ACTTCTAT TCTCTAACTC TTCTTCGCTG CTCAATAAAA TATCTCTGCT TGGAAAAATG TCACGCGTAA AAATTAGACG AGGCGACAAA AGTTCTACAC GTAAAACAAA AACTATTCAC TCTTCTTATT ACGGTAAAGG CGAAACCAGCAAGAAGACCAGATTATACT TACAAGAGATGAGCAGTGTTCAACT TTCGAGGGGCGATTTTCATAGCATCTTCACCAATAAGCAAAGGTACGATAATCC CACCGGTGGCGTTTATCAAGT TTATAACACCAGGAAATCTGATGGGGCTAACAG

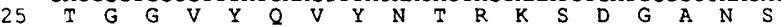
CAACAGAAAGAATTTGATCATGATTTCCGATGGTATTTACCATATGAAGGCTCT GTTGAGAAACCAAGCTGCATCCAAGTTCCAGTCAATGGAACTACAAAGGGGTGA

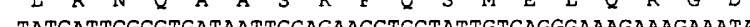

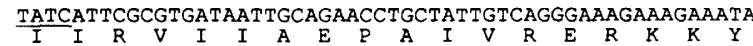
CGTTCTTTTAGTAGATGACTTTGAGTTGGTCCAGTCGCGTGCTGATATGGTCAA $\begin{array}{llllllllllllllllllllllll}V & L & L & V & D & D & F & E & L & V & Q & S & R & A & D & M & V & N\end{array}$ CCAAACTAGTACTTTTTTGGATAACTATTTCTCAGAGCATCCAAATGAAACCTT AAAAGACGAAGATATAACTGACAGTGGTAATGT TGCCAATCAAACAAACGCCAG CAATGCTGGTGTCCCTGATATGCTGCATTCAAACTCAAACTTGAATGCAAATGA GAGAAAATTCGCCAATGAAAACCCTAATTCGCAAAAAACCAGACCAATTTTTGC

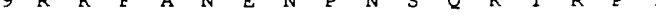
CATCGAACAACTGTCTCCATACCAAAACGTTTGGACTATCAAAGCAAGAGTTTC CTACAAGGGAGAAATTAAAACGTGGCACAATCAAAGAGGTGATGGTAAACTATT CAATGTCAACTTCTTGGATACCTCTGGAGAAATCCGAGCCACGGCGTTTAATGA TTTTGCTACAAAATTTAAACGAAATTTTACAAGAAGGCAAAGTATACTATGTATC AAAGGCAAAACTCCAACCAGCTAAGCCCCAATT TACTAATCTAACACACCCTTA TGAACTGAATTTGGATAGAGACACTGTTATAGAAGAATGTTTCGATGAAAGTAA

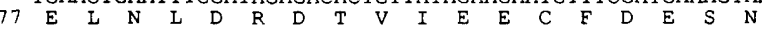
TGTTCCGAAAACCCATTTCAATTTCATCAAACTAGATGCTATTCAGAACCAGGA AGTAAATTCCAACGTAGACGTCCTCGGTATTATCCAAACTATAAACCCACATTT TGAGCTAACTTCAAGGGCTGGGAAGAAATTCGATCGTCGTGACATCACAATTGP TGACGACTCTGGGTTTTCTATCTCTGTTGGCCTATGGAATCAGCAAGCCCTTGA $67 \underset{\mathrm{F}}{\text { TTCAACCTTCCTGAAGGTTCTGTTGCTGCCATTAAAGGTGTTCGTGTGACGGA }}$ TTTTGGTGGCAAATCTTTGTCTATGGGATTTTCTAGTACCCTGATTCCGAATCC

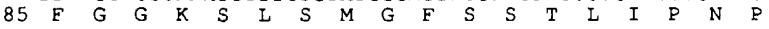
AGAAATTCCTGAGGCATATGCCTTAAAGGGTTGGTATGATTCCAAGGGCCGCAA CGCAAACTTCATCACTTTAAAGCAAGAACCCGGTATGGGTGGTCAATCGGCTGC TAGCTTAACAAAATTCATTGCI CAGCGTATTACTATTGCTAGAGCTCAAGCTGA AAATCTAGGAAGAAGCGAGAAAGGTGACTTTTTTAGTGTTAAAGCTGCTATAAG

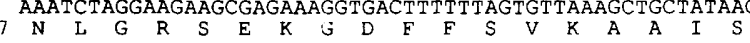

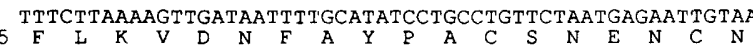
TAAGAAAGTTCTGGAACAGCCTGATGGTACTTGGAGATGTGAGAAGTGCGACAC CAATAATGCAAGGCCAAATTGGAGATACATCTTGACAATATCAATTATTGACGA AACCAATCAACTATGGCTCACTTTATTTGACGACCAAGCTAAACAATTATTGGG

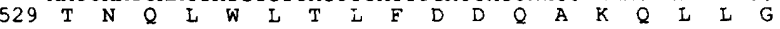

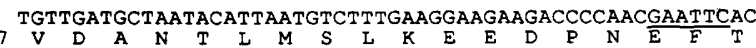
AAAAATTACTCAAAGTATCCAAATGAACGAATATGACTTTAGGATTAGAGCGCG TGAGGATACATACAATGATCAAAGCAGAATTAGATATACCGTTGCTAACCTACA CAGCTTGAATTACAGGGCTGAAGCCGACTATCTTGCCGATGAGTTATCCAAGGC TTTGTTAGCTTAaTGTATCAAATAATCAAGTACTATTTAATCTATGTAACATAT 19 L L A

GAGAAATGTA AAAAAAAAAC TTCTATTTTCG TCAAGTTTTTT GAAGGGCGGT TCAGCATCTC TTGATGACTG GATATGAAAC TACACGTTCA GACATATGAA TTTGAACCCA TAATGCACAA ATGAATAAAA ATGCTAACAA ATTCTAATTA ATGGCATGGT ACTAACACA TCAAATAACA AAGCTT
HindIII
RFA2

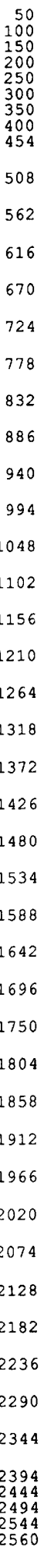

CTGCAGACAG CAATAATTTT GCATGCAATA ACGTCTCCAT TCAA CCACTAGTTT ACTTTTTGCC TGGTCTGATA GCTTCTTTTT AGCAATTCCT TTGGCTCGA TGAGCTTCCA TAGATAATTA TCGCCATATA CGAACGCGI TAGGAAECGC GTGGAAGTAA TGTGGCAAAA TCGATAGCGA CTATCTAGM TAGGAATTGGAGGATTTGCTCTTTICTGCATCATTTTTTTTATTT TTATTGGCGAATGTTAAAATTACTAACAATGGATGGGATTCCAAT ACAGCCTATCAACCATATAACGAATATTCATCAGTAACGGGCGGT GGCTTTGAGAACTCTGAGTCCCGCCCAGGTAGTGGGGAGTCGGAA ACTAACACTAGAGTTAACACCTTGACACCTGTGACGATCANACAA ATICTAGAGTCCAAACAGGATATTCAGGACGGCCCCTTCGTTTCO

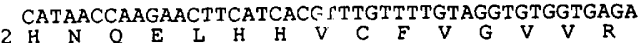

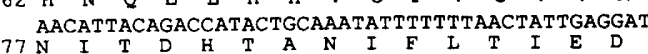

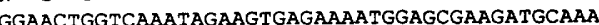
$92 \mathrm{G} T \mathrm{~T}$ Q I E V R K W S E D A N GACTTGGCTGCCGGTAACGATGACTCTTCTGGTAAAGGTTATGGT $107 \mathrm{D} \quad \mathrm{L}$ A A A G N TCGCAAGTCGCCCAACAATTTGAAATTGGCGGTTACGTAAAAGTT $37 \mathrm{TTTGGTGCTTTGAAAGAGTTTGGTGGTAAGAAAAATATACAGTAT}$ GCGGTGATTAAGCCCATAGATICATTCAATGAAGTTTGACGCAT

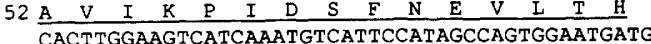
A H S I A S G M M AAACAACCTTTGGAGAGTGCATCCAACAACAATGGGCAATCATTA 1000 $182 \mathrm{~K} Q \mathrm{Q} \quad \mathrm{P}$ L E S S A S N N N N TTTGTCAAGGATGATAACGATACATCTTCCGGCTCCAGTCCGTTA 1045 CAAAGAATTCTAGAATTTTGTAAGAAGCAATGTGAGGGCAAAGAC GCTAATTCATTCGCTGTTCCCAITCCATTGATCTCGCAATCCTTG 1135 AATTTGGATGAAACTACCGTCAGAAACTGCTGTACGACCTTGACT 1180 $242 \mathrm{~N} \quad \mathrm{D}$ E T I GACCAGGGTTTTATCTACCCAACTTTTGATGACAATAACTTCTTT 1225

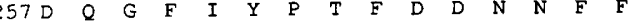
GCCCTATGAAAATATATAGATTATTTTTTTAGCATTTCTTAGTAT 1270 $272 \mathrm{~A}$ L

TCGTTTGTGT ATTTCTACTA GGTAAGTACC AAAATTTGCC GGAAATAGAG TGGAAAATGG AACCCGTTC $X \mathrm{mn} I$

RFA3

PvuII

CAGCTGCAAG CACCCAACAA GAACAGATGA CAGCCAACAG TCGTTGACTA AGCTAAIGGG CCACTGCTGA GAAGCATCCA CCGCCCATGC CATGGTTGGA ATCATGACAA GTCGCCCTAT ATAATGCCTT CGTTCTTTAA TATTGACGCG OCAAATGT AATAAGG TACCAGTAACACAAGT AAAAATGGCCAGCGAAACACCAAGAGTTG ACCCCACAGAAATCTCCAACGTCAATGCTCCTGTGTTTAGGATAA $9 P_{T}$ E I S N V N A P V F R I I TAGCGCAAATCAAATCACAACCCACTGAATCTCAGTTGATTTTAC AATCGCCAACCATATCATCGAAAAACGGCAGCGAGGTTGAAATGA

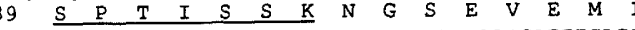
TTACGTTGAACAATATTCGTGTATCTATGAATAAAACATTTGAGA $69 \underset{D}{\text { TCGACTCGTGGTATGAGTTTGTTTGCAGGAACAATGATGACGGCG }}$ AGCTAGGATTTTTGATTCTAGACGCTGTACTATGCAAATTCAAGG 84 I $\quad G \quad F \quad L \quad I \quad L \quad D$ A $99 \underset{N}{\text { AGAACGAAGATTTAAGCTTAAACGGTGTGGTTGCTTTACAGAGAC }}$ TATGTAAGAAATACCCAGAAATATACTAGCTAAAATCGCTTTTAT

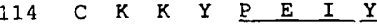
TCTTACCTTT ATGTACTGTT GCCTCTATAT GTCTTCCCTT TTATAGATGT ATAGATAGAT AAATGAATGT GTACTTGCTG CCTTAACGCC TTCCGCTAAA AACTTTTTGA TATTTATTTT ATTTTTAACC TITCCTGACT FCAACCCTTA CTGTAATGAT GATAGTAGAA GCCGTCTATT TTTCATACTT TTCTCATGTT GATTTTCCTT GCAGACAAA ACAATCTCTT GGATGGTTTG CGTAGTTTAC TCCCGATGAT ATC
40
80
120
160
200
240
285

330
375
40
420
465
510
5
555
600
600
645
6
685
725
765
805
845
885
925
965
987

Figure 2. Nucleotide sequence of the RFA1, RFA2, and $R F A 3$ genes and flanking DNA. The predicted amino acid sequence is shown in the single-letter code. Underlined peptides correspond to sequences obtained from direct amino acid sequencing of tryptic peptides. Underlined nucleotides represent restriction enzyme cleavage sites used in the construction of deletion alleles. In the RFA2 sequence bold nucleotides are used to represent consensus splice site sequences, and bold underlined nucleotides represent the oligonucleotide primer sequences used to isolate the RFA2 cDNA by PCR. MluI motifs are boxed. 
RFA1 contains a single open reading frame (ORF) encoding 622 amino acids. The predicted protein has a molecular mass of $70.4 \mathrm{kD}$ and is very rich in asparagine $(\mathrm{N})$ and charged residues. The DNA sequence of RFA1 is identical to that of a previously identified gene, RPA1. Only the restriction map upstream of the gene differs from that obtained by Heyer et al. (1990). As originally noted, this gene encodes a zinc finger motif (amino acids 486-508) that may mediate its DNA-binding activity.

In keeping with the original identification of this protein in yeast, we refer to the genes encoding the subunits of RF-A as RFA genes. The use of this nomenclature, rather than $R P A$, has the advantage of avoiding confusion with the established gene symbols for the subunits of RNA polymerase I and acidic ribosomal proteins (Riva et al. 1986; Memet et al. 1988; Mitsui and Tsurugi 1988).

$R F A 2$ contains an intron with consensus splice-site signals (Fig. 2, bold nucleotides). To confirm that the message encoded by RFA2 was spliced, a cDNA product was obtained by polymerase chain reaction (PCR). Total RNA was first reverse-transcribed with random hexamer primers and reverse transcriptase, and then subjected to PCR with oligonucleotide primers flanking the putative intron (bold, underlined nucleotides in Fig. 2). Polyacrylamide gel electrophoresis of the reaction products revealed two specific bands at 291 and $183 \mathrm{bp}$ (Fig. 3A). The $291-b p$ band is predicted from the genomic sequence of $R F A 2$. It was probably due to genomic DNA present in

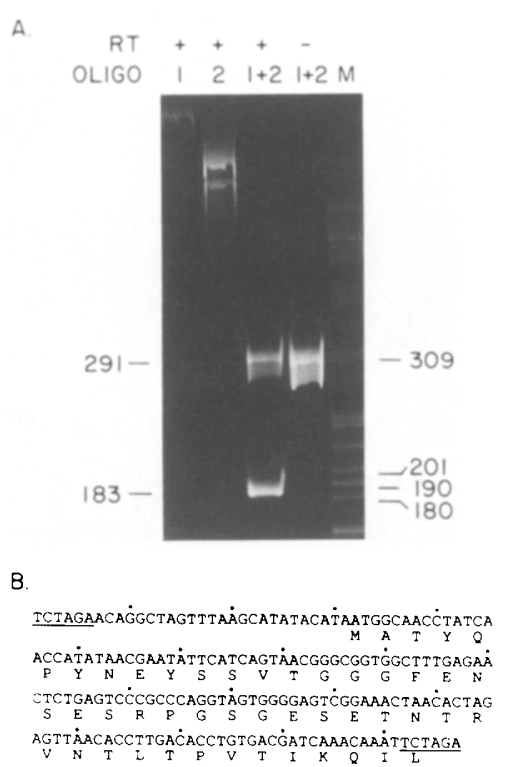

Figure 3. The RFA2 gene contains an intron. Total yeast RNA was reverse transcribed with random primers and subjected to PCR. (A) PCR reaction products following polyacrylamide gel electrophoresis. (OLIGO) Oligonucleotides used as primers in the PCR reaction, shown as bold underlined nucleotides in Fig. 2 ; (1) the 21-bp amino-terminal primer; (2) the 24-bp carboxyterminal primer. (RT) Reverse transcriptase; (M) pBR322 HpaII digest. $(B)$ Sequence and translation product of the 183-bp band following $\mathrm{XbaI}$ digestion. Underlined bases indicate the $\mathrm{XbaI}$ recognition sequence.

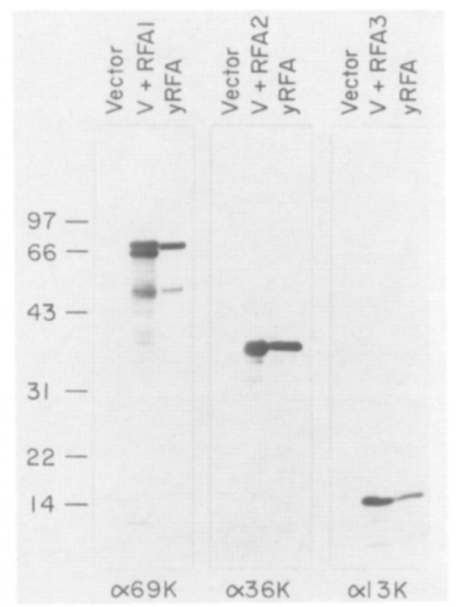

Figure 4. RFA1, RFA2, and RFA3 genes encode the subunits of RF-A. Total bacterial cell extract from induced cells carrying either the expression vector alone or a recombinant plasmid containing the indicated gene was separated by $17 \%$ SDS-PAGE and transferred to nitrocellulose. Strips were separated and probed with the respective affinity-purified rabbit antibody raised against the individual subunits of RF-A from $S$. cerevisiae. Purified RF-A was included as a control. The $50-\mathrm{kD}$ band recognized by the $\alpha 69 \mathrm{~K}$ antibody is a prominent breakdown product of the $69-\mathrm{kD}$ subunit.

the RNA preparation, because it was obtained even in the absence of reverse transcriptase (Fig. 3A, lane 4). The reverse transcriptase-dependent band of $183 \mathrm{bp}$ was the size expected if it was derived from the spliced message. The sequence of this fragment, shown in Figure 3B, confirmed the exon/intron boundaries suggested by the splice site consensus sequences.

The predicted $R F A 2$ protein is 273 amino acids with a molecular mass of $29.9 \mathrm{kD}$. The protein is rich in asparagine and acidic residues (calculated pI 4.6). RFA2 has no significant similarity to any protein in the current sequence data bases except for its human homolog (see below). The RFA3 gene contains a single ORF encoding 121 amino acids. The predicted protein has a molecular mass of $13.8 \mathrm{kD}$ and, like $R F A 2$, is rich in asparagine and acidic residues (calculated pI 4.5). RFA3 has no significant similarity to any protein in the current sequence data bases.

Conclusive proof that these genes encode the subunits of RF-A was provided by immunoblotting bacterially produced proteins with antibodies against yeast RF-A. The gene for each subunit was expressed in $E$. coli with the T7 expression system (Studier et al. 1990). Total cellular extracts from bacteria carrying recombinant plasmids or the $\mathrm{T} 7$ vector alone were subjected to SDS-PAGE and immunoblotted with affinity-purified antibodies raised against the individual subunits of RF-A purified from S. cerevisiae. As shown in Figure 4, each antibody specifically recognized antigen encoded by the appropriate recombinant vector. The antigens were also the appropriate molecular mass as judged by comigration with 
authentic RF-A subunits. The protein encoded by RFA1 appears as two strong bands, perhaps due to internal translation start sites or to proteolytic degradation (Fig. 4 , second lane). The identification of the RFA genes by a method (immunoblotting) that is independent of the method used to clone them (protein sequencing) proves their identity.

\section{RFA genes are essential}

To determine whether the RF-A protein performed an essential function, most of the coding region for each of the RFA1, RFA2, and RFA3 genes was replaced by the TRP1 gene, as shown in Figure 1. These three chromosomal deletion alleles were used individually to transplace the corresponding wild-type genes in a diploid yeast strain. Tetrad dissection of each of the three heterozygous diploids yielded no more than two viable spores, and all viable haploid spores exhibited a $\operatorname{Trp}^{-}$ phenotype $(13,11$, and 15 tetrads, respectively, for rfa1::TRP1, rfa2::TRP1, and rfa3::TRP1; data not shown). Lethality was caused by the disruption of the RFA genes because the same diploid strains gave three or four viable spores when they carried the respective gene on single or multicopy plasmids prior to sporulation (data not shown). In these cases $\operatorname{Trp}^{+}$haploids were obtained that were always prototrophic for the plasmid marker. The rescuing DNA fragments are those shown in Figure 2, suggesting that all essential coding and promoter elements are contained on these fragments. Haploid strains carrying the disrupted RFA2 gene were rescued by a "cDNA" version of the gene in which the 279-bp XbaI genomic fragment was replaced by the 171bp XbaI cDNA fragment obtained by PCR. These haploids had no observable phenotype, suggesting that the intron of RFA2 was not part of an important regulatory mechanism.
Inspection of the terminal phenotype by light microscopy revealed that all germinated spores, regardless of the specific gene disrupted, arrested as budded and multiply budded cells (Fig. 5). Often the dead cells were larger than viable siblings; they appeared swollen and occasionally contained buds on buds. Dissection of individual microcolonies from each disruption revealed approximately equal numbers of budded and aberrantly budded cells (data not shown). Figure 5 indicates, however, that the number of divisions that each germinated spore was capable of undergoing differed, depending on which gene was disrupted. Loss of RFA1 resulted in the most severe arrest, usually at the 2- to 4-cell stage. Loss of $R F A 2$ resulted in arrest at the 8- to 16-cell stage, whereas the loss of $R F A 3$ resulted in arrest at the 16- to 32-cell stage. The simplest interpretation of these results is that the RF-A complex is essential for viability and that the individual subunits of the complex are either not present in equal amounts or they turn over at different rates.

\section{Regulation of RFA gene expression}

In $S$. cerevisiae most, if not all, of the genes encoding enzymes involved in DNA synthesis are expressed in a cell-cycle-dependent manner, with mRNA levels peaking at $\mathrm{S}$ phase. This regulation has been shown to occur at the level of transcription and to be mediated by promoter elements containing the restriction enzyme-recognition sequence for MluI (Pizzagalli et al. 1988; Lowndes et al. 1991). MluI recognizes a 6-bp sequence containing $4 \mathrm{G} / \mathrm{C}$ residues and, consequently, rarely cleaves in the A/T-rich DNA of yeast. We observed that this sequence occurs twice in each promoter for $R F A 1$ and RFA2 (Fig. 2, boxed nucleotides). Although the cleavage site is not found in the RFA3 gene, a degenerate form of the sequence is found in the $R F A 3$ promoter

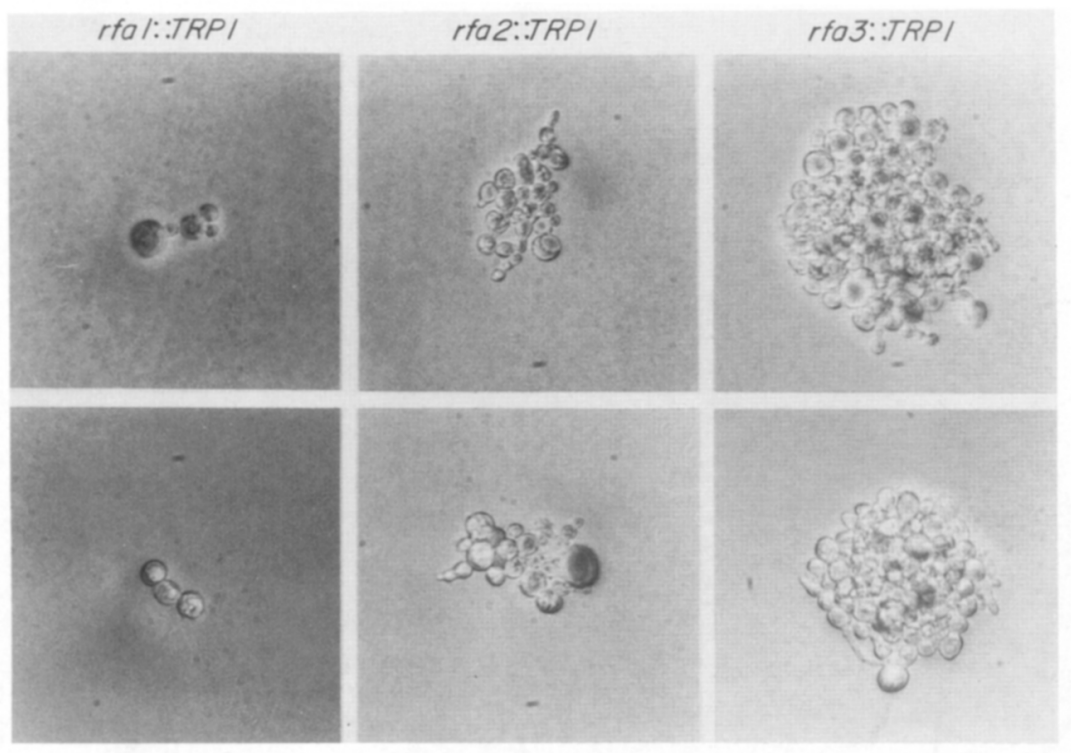

Figure 5. Terminal phenotype of the rfa1::TRP1, rfa2::TRP1, and rfa3::TRP1 gene disruptions. Microcolonies from tetrads exhibiting $2: 0$ segregation were photographed $48 \mathrm{hr}$ after dissection using DIC optics. Magnification, $400 \times$. 
(boxed in Fig. 2). Again the sequence appears to be duplicated and in each case is a 5 out of 6 match to the authentic ACGCGT.

To determine whether the RFA genes were expressed in a cell-cycle-dependent manner, yeast cells were synchronized by release from $\alpha$-factor block and samples were harvested at 15-min intervals for Northern analysis. Inspection of the budding pattern (Fig. 6A) indicates that synchrony was maintained for at least two generations. Northern blot analysis shows fluctuations in the abundance of all three RFA messages. The message for each gene peaks at 30,90 , and 150 min after release /Fig. $6 \mathrm{~B})$. Each of these time points corresponds to the appearance of small budded cells. As bud emergence is taken to be a landmark for the onset of DNA replication, the expression of the three RFA genes is coordinate and appears to occur in late $G_{1}$ and $S$ phase. This expression pattern is consistent with a complex involved in DNA replication.

\section{Similarity to human RF-A}

The cDNA encoding the $34-\mathrm{kD}$ subunit of human RF-A (RP-A) has been cloned and sequenced (Erdile et al. 1990). A comparison of the human gene product to that of the

A

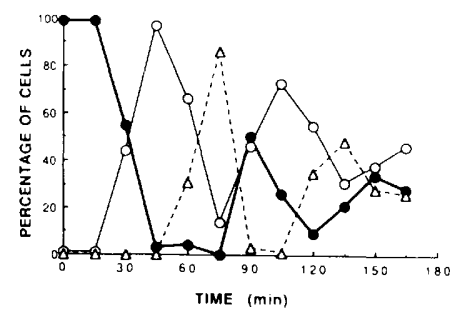

$\mathrm{B}$

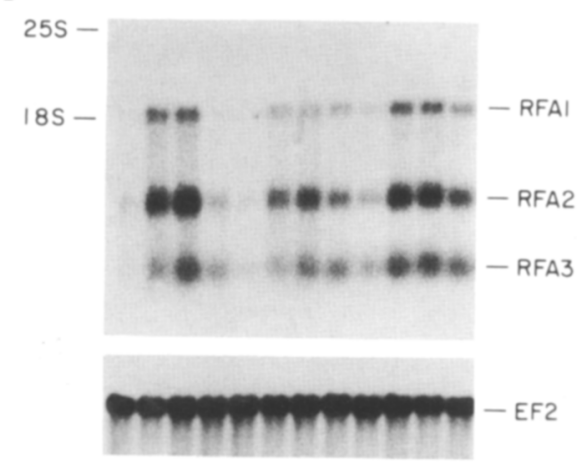

Figure 6. $R F A 1, R F A 2$, and $R F A 3$ genes are coordinately expressed at the $G_{1} / S$-phase boundary. Strain W303-la was synchronized by $\alpha$-factor arrest and release. Aliquots of the culture were removed at 15 -min intervals and either fixed for determining the budding index $(A)$ or processed for Northern blotting $(B \mid$. $(A)(O)$ Unbudded; (O) small buds; $(\triangle)$ large buds. One nitrocellulose filter was probed with ${ }^{32} \mathrm{P}$-labeled antisense RNA specific for $R F A 1, R F A 2$, and $R F A 3$ messages. A duplicate filter was probed with ${ }^{32} \mathrm{P}$-labeled antisense RNA specific for TEF21 to detect translation elongation factor 2 (EF-2) message as an internal standard. Small buds are taken to be less than half the size of the mother. yeast RFA2 gene is shown in Figure 7. The proteins are approximately the same size (the yeast protein is only 3 amino acids larger); however, gaps have been introduced to maximize the alignment. Overall, the proteins are $29 \%$ identical and $44 \%$ similar, allowing for conservative amino acid substitutions. The similarity extends equally throughout the length of the protein except for one segment near the center (bold in Fig. 7). This segment, which comprises 39 residues uninterrupted by gaps, is $49 \%$ identical and $59 \%$ similar allowing for conservative substitutions. This region may identify a functionally important domain of the protein, perhaps mediating interactions with the other subunits of RF-A.

Attempts to rescue the $r f a 2:: T R P 1$ deletion strain with the human cDNA failed. Diploids heterozygous for the rfa2::TRP1 allele were transformed with multicopy plasmids carrying either the human cDNA encoding the 34 $\mathrm{kD}$ subunit of RF-A (RP-A, provided by L. Erdile and T. Kelly) or the yeast RFA2 cDNA under the control of the inducible galactose promoter. Following growth on galactose the diploids were sporulated and dissected onto galactose-containing plates. The strain carrying the human clone yielded no more than two viable spores while the strain carrying the yeast clone yielded three or four viable spores (data not shown). Immunoblotting with monoclonal antibodies directed against the human protein indicated that the human $\mathrm{p} 34$ protein was expressed when induced in wild-type yeast. Furthermore, expression of the human protein had no phenotypic effect on wild-type yeast. Interestingly, yeast strains overexpressing the RFA2 gene from this inducible promoter produced smaller colonies than cells carrying the expression vector alone (data not shown). This result suggests that improper expression of an RF-A subunit is harmful to cell growth, perhaps due to interference with regulated pathways or to an imbalance in the RF-A subunits.

\section{Discussion}

Several lines of evidence suggest that RF-A is the primary eukaryotic single-stranded DNA-binding protein involved in DNA replication. The biochemistry of SV40 DNA replication has shown that RF-A is an essential factor involved in both the initiation and elongation stages of viral DNA replication. Studies from both human and yeast cells indicate that RF-A is a highly conserved protein in its subunit structure, DNA-binding activity, and post-translational modification. The current study describing the characterization of the genes encoding RF-A from $S$. cerevisiae confirms the essential nature of this protein complex in vivo. The requirement for all three genes argues that RF-A functions as a complex; the absence of any single subunit results in lethality.

The terminal phenotype of budded and multiply budded cells suggests that entry into the cell division cycle is unaffected by the loss of RF-A activity. This arrest phenotype is consistent with an S-phase defect disconnected from the budding and growth cycles of the cell. It was found that the number of divisions that each null mutant was capable of undergoing before arrest differed, 


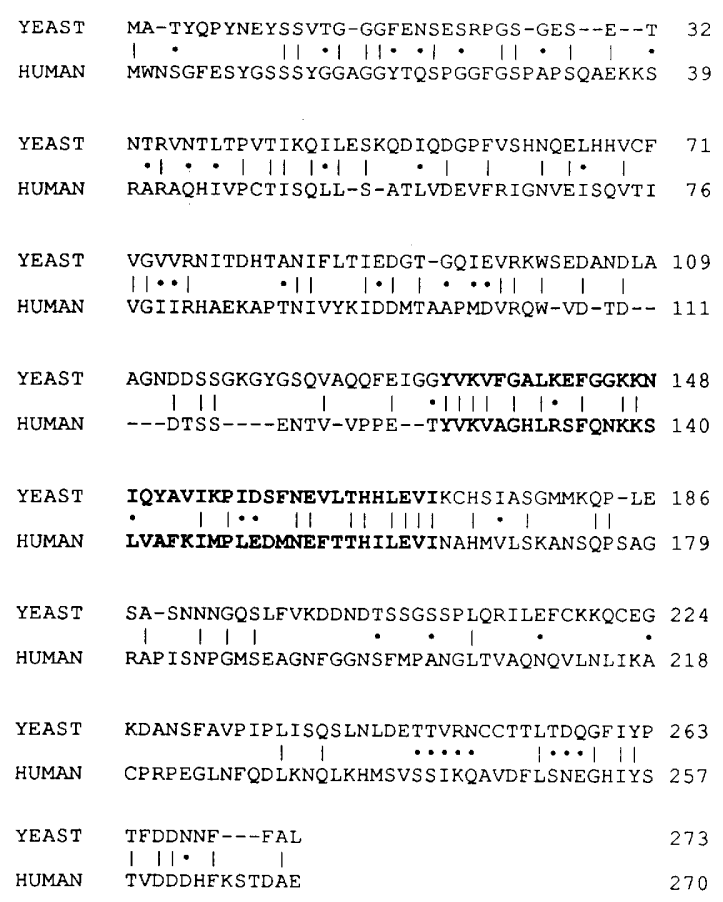

Figure 7. Comparison of the $34 / 36-\mathrm{kD}$ subunits of RF-A from human and yeast cells. Shown are the complete amino acid sequences of the $34 / 36-\mathrm{kD}$ subunits of RF-A. Gaps have been introduced to maximize the alignment. Conservative amino acid changes are indicated by dots, according to the criteria of Dayhoff et al. (1983). A block of amino acids showing somewhat greater similarity than the rest of the protein is indicated in boldface type.

depending on which subunit was disrupted. One possible interpretation of this result is that the size of the microcolony reflects how frequently the individual subunits are required. For example, the $13-\mathrm{kD}$ subunit may be required in a pathway that occurs rarely. The cell is then capable of undergoing many rounds of division before encountering a requirement for this subunit. However, given the consistency with which these phenotypes were exhibited, we feel that a simpler explanation is that the cells arrest at different times because of differences in the abundance of the free subunits or differences in their rate of turnover. This explanation predicts that the 13$\mathrm{kD}$ subunit is either more stable or more abundant than either of the other two subunits.

RF-A may perform additional functions that contribute to its null phenotype. Human RF-A has been shown to be involved in the process of DNA excision repair with a cell-free system (Coverley et al. 1991). It was suggested that RF-A may aid in the recognition of ssDNA at sites of DNA damage, as well as in the recruitment of DNA polymerase to the gapped template. E. coli SSB and adenovirus ssDNA-binding protein could not substitute for RF-A in these reactions, suggesting that specific protein-protein reactions are required (Coverley et al. 1991). RF-A may also function in the process of genetic recombination similar to $E$. coli SSB and T4 gene 32 protein. A proteolytic fragment of the $69-\mathrm{kD}$ subunit of yeast RF-A, which retained ssDNA-binding activity, was purified on the basis of its stimulation of a yeast-strand exchange protein (Heyer et al. 1990). Differences in the colony sizes of the null mutants may therefore be affected by the loss of an auxiliary function associated with a specific subunit.

The specific functions of the individual subunits are still unclear. The observation that the $69-\mathrm{kD}$ subunit may be a zinc finger protein is consistent with its biochemical activity of binding ssDNA, and it is likely that at least one essential role of the $69-\mathrm{kD}$ subunit is to stabilize ssDNA. Interestingly, if the only role of the RF-A complex was to bind to ssDNA, this should be accomplished by the $69-\mathrm{kD}$ subunit alone because SSB activity is detected in the isolated subunit (Brill and Stillman 1989; Wold et al. 1989; Kenny et al. 1990). The requirement for both the 36- and 13-kD polypeptides indicates that RF-A is a multifunctional complex and that the smaller subunits play other essential roles.

The protein sequences of the $36-$ and $13-\mathrm{kD}$ subunits have not shed light on what these additional functions might be. They do not contain any obvious DNA-binding motifs nor do they share any obvious sequence motifs that might mediate their own protein-protein interactions. The interactions that maintain the subunits in a stable complex are extremely strong; the complex from both species is resistant to high concentrations $(6 \mathrm{M})$ of urea. It seems reasonable that the two smaller subunits are involved in mediating protein-protein interactions with other components involved in DNA replication, repair, and recombination. It has been shown that antibodies directed against the human $34-\mathrm{kD}$ subunit, as well as the $70-\mathrm{kD}$ subunit, inhibit SV40 DNA replication in vitro (Kenny et al. 1990; S. Din and B. Stillman, in prep.). Antibodies directed against both subunits also inhibit DNA excision repair in vitro (Coverley et al. 1991). Although antibody binding to the $34-\mathrm{kD}$ subunit may affect the DNA-binding activity of the complex, the effects of the anti-34-kD antibody may be explained more easily by the inhibition of protein-protein interactions involving the $34 / 36-\mathrm{kD}$ subunit of RF-A. Candidates for such interacting proteins include the DNA polymerases $\mid \alpha$ and $\delta$ ), as well as other proteins involved in DNA replication such as primase, RF-C, and PCNA. In the cell, RF-A may also interact with initiation factors that function prior to the onset of DNA synthesis. The in vitro mutagenesis of RFA2 and RFA3 provides a genetic method of identifying components of the DNA replication, repair, and recombination machinery that interact with RF-A through these subunits.

Given the requirement for three intact genes, it is odd that none of the RFA genes correspond to known temperature-sensitive mutations or $c d c$ genes in yeast. One possible explanation is that the subunits exist as individual functional domains that are so structurally restricted that single point mutations and, hence, temperature-sensitive phenotypes, are not tolerated. More likely, however, the RF-A genes are part of the "genenumber" paradox. Harris and Pringle (1991) have shown that even the use of multiple different mutagens fails to 
uncover essential genes that have been identified by molecular techniques. These workers suggest that differential repair processes may play a role in limiting the number of mutations that can be identified by classical genetics. On the other hand, if the arrest phenotype of the temperature-sensitive mutants resembles that of the null mutants, these mutants would be overlooked in a Cdc screen because of their complex phenotype: a mixture of budded and multiply budded cells as well as cells with buds on buds. The construction of temperaturesensitive alleles of the RFA genes by in vitro mutagenesis and reverse genetics should circumvent these problems.

The RFA genes are expressed periodically with mRNA levels peaking at the $G_{1} / S$ phase boundary. We believe that this regulation is mediated by known promoter elements and therefore occurs at the level of transcription. The promoters of most genes encoding proteins involved in DNA synthesis in yeast contain a single MluI site, but additional CGCG core elements have been found to be important (Pizzagalli et al. 1988; Bauer and Burgers 1990; Lowndes et al. 1991). The promoters of both RFA1 and RFA2 contain two MluI recognition sequences. The $R F A 3$ gene is unique in that no MluI sequence is found in its promoter, yet it maintains its S-phase regulation. Therefore, the reiteration of a more degenerate motif such as ACGCGX may be sufficient for S-phase transcriptional regulation.

In contrast to the periodic transcription of these genes, previous cell-cycle studies in yeast have shown that the levels of RFA2 protein do not fluctuate throughout the cell cycle (Din et al. 1990). Thus, one must question whether the transcriptional regulation seen in this family of genes is important for driving the cell cycle or whether it is simply fortuitous. Conceivably, the regulation may be important for maintaining the stoichiometry of essential replication components. In support of this hypothesis, we noticed that when the RFA2 gene was overexpressed on a galactose-inducible promoter, the cells were viable but formed small colonies. This effect could be due to an imbalance of subunits. The importance of balanced gene expression in protein complexes has been demonstrated previously in yeast. Meeks-Wagner and Hartwell (1986) have shown that when either pair of the yeast histone genes $(\mathrm{H} 2 \mathrm{~A} / \mathrm{H} 2 \mathrm{~B}$ and $H 3 / H 4$ ) was overexpressed relative to the other pair, cells displayed an increase in chromosome loss. Their data suggests that proper stoichiometry is required in the assembly of the nucleosome core. Similarly, the overexpression of one subunit of RF-A may result in incorrect assembly of the complex. Alternatively, the overexpression of a subunit involved in protein-protein interactions may result in the sequestering of essential factors. Further experiments will be necessary to distinguish between these possibilities.

A comparison of the human and yeast RFA2 genes indicates that little amino acid sequence is conserved between the yeast and human protein. Genetically, it is found that the human p34 subunit does not substitute for the homologous yeast protein even though the syn- thesis of human protein was observed by immunoblot. Given the structural and functional similarity of RF-A from both yeast and human cells, these results were unexpected. The subunits have closely maintained their relative sizes and post-translational modifications while tolerating significant changes in amino acid sequence. This suggests that there is selective pressure to maintain the overall subunit structure of RF-A. We consider the structural and functional similarity of yeast and human RF-A to be a strong argument for a common mechanism of initiation and elongation in eukaryotic DNA replication.

The SV40 system has been used as a model to biochemically identify conserved replication factors in $S$. cerevisiae. These factors will aid in the establishment of a yeast in vitro system for the study of eukaryotic DNA replication with chromosomal origins. The identification of RFA genes in yeast presents a complementary approach to solving this problem; a genetic analysis of RF-A should identify new factors involved in the mechanism and regulation of eukaryotic chromosomal DNA replication.

\section{Materials and methods}

Yeast strains and RF-A purification

All DNA cloning and expression experiments were performed with the standard wild-type yeast strain W303-1a (Wallis et al. 1989|. Disruption experiments were performed with the isogenic diploid strain W303 by using the method of Rothstein (1983).

RF-A was purified essentially as described (Brill and Stillman 1989 ) except that the starting material for the purification was dried S. cerevisiae from Sigma (YSC-1). Dried yeast (100 grams) was first rehydrated and washed once in distilled water $\left(4^{\circ} \mathrm{C}\right)$, yielding 220 grams of yeast cells wet weight. The yield from this amount of material ( $400 \mu \mathrm{g}$ of RF-A) was essentially the same as that obtained from laboratory strains. Because the cells had been grown to saturation before drying (all cells were unbudded) the $36-\mathrm{kD}$ subunit conveniently migrated in SDS-PAGE gels as a single band at the unphosphorylated position. This is expected for RF-A isolated from $G_{1}$ phase cells (Din et al. 1990). Attempts to perform amino-terminal protein sequencing on the subunits of RF-A failed, suggesting that their termini were blocked.

\section{Isolation of tryptic fragments and protein sequencing}

Purified RF-A $(250 \mu \mathrm{g})$ was precipitated by the addition of TCA to $10 \%$ and incubation at $0^{\circ} \mathrm{C}$ for $30 \mathrm{~min}$. The sample was pelleted in a microcentrifuge for $10 \mathrm{~min}$ and washed twice with acetone $\left(-20^{\circ} \mathrm{C}\right)$. The visible pellet was dried briefly and $80 \mu \mathrm{l}$ of $0.1 \mathrm{M}$ Tris $(\mathrm{pH} 8.0)$ was added. The protein was solublized by the addition of $80 \mu \mathrm{l}$ of $2 \times$ SDS-PAGE sample buffer, heated at $60^{\circ} \mathrm{C}$ for $10 \mathrm{~min}$, and separated electrophoretically in three lanes (6-mm wide) of a $1.5-\mathrm{mm}$-thick $12 \%$ SDS-PAGE gel. The protein was transferred to nitrocellulose (Schleicher \& Schuell, BA85) with a Hoeffer wet transblotter and $25 \mathrm{~mm}$ Tris/200 mM glycine $/ 20 \%$ methanol as buffer. Transfer conditions were 0.5 amp for $2 \mathrm{hr}$ at $4^{\circ} \mathrm{C}$. Following transfer, the nitrocellulose was stained with Ponceau S $(0.1 \%$ in $1 \%$ acetic acid) for $1 \mathrm{~min}$ and destained in $1 \%$ acetic acid for $2 \mathrm{~min}$. Transfer of the 36- and $13-\mathrm{kD}$ subunits was estimated to be essentially complete while $\sim 30 \%$ of the $69-\mathrm{kD}$ subunit transferred out of the gel. The 
stained protein bands were excised carefully from the excess nitrocellulose, and the appropriate bands were pooled into separate microcentrifuge tubes. Proteins were destained by treatment with $0.2 \mathrm{~N} \mathrm{NaOH}$ for $1 \mathrm{~min}$, followed by three washes with distilled water. The nitrocellulose strips were then blocked with $1.2 \mathrm{ml}$ of $0.5 \%$ polyvinylpyrrolidone- 40 (PVP-40) in $0.1 \mathrm{M}$ acetic acid for $30 \mathrm{~min}$, washed six times with distilled water, and diced into $1 \times 1-\mathrm{mm}$ squares. The remaining water was removed, and 75,60 , and $40 \mu \mathrm{l}$ of $0.1 \mathrm{M} \mathrm{NaHCO}_{3}(\mathrm{pH} 7.9) /$ acetonitrile ( $95: 5$ by volume) were added, respectively, to the tubes containing the 69-, 36-, and 13-kD subunits. Trypsin $\mid 3.5$, 3.5 , and $1.6 \mu \mathrm{l})(1 \mathrm{mg} / \mathrm{ml}$ in $1 \mathrm{mM} \mathrm{HCl}$; Worthington, TPCK treated) was added, respectively, to the tubes and the samples were incubated at $37^{\circ} \mathrm{C}$ for $16 \mathrm{hr}$. This reaction was estimated to have an enzyme-substrate ratio of $1: 20(\mathrm{wt} / \mathrm{wt})$. The supernatant was removed, and the nitrocellulose chips were washed with an equal volume of $0.1 \mathrm{M} \mathrm{NaHCO}_{3}$ ( $\mathrm{pH} 7.9$ )/acetonitrile ( $95: 5$ by volume). The supernatants were pooled and frozen at $-20^{\circ} \mathrm{C}$.

Reverse-phase chromatography was performed on a HewlettPackard 1090 liquid chromatograph with a $2.1 \times 220-\mathrm{mm}$ Aquapore RP-300 column $\left(\mathrm{C}_{8}\right.$ resin, Applied Biosystems $)$. Columns were run at room temperature with a flow rate of 0.1 $\mathrm{ml} / \mathrm{min}$ and the following conditions: isocratic at $5 \%$ B for 15 min; a linear gradient from $5-50 \% \mathrm{~B}$ in $45 \mathrm{~min}$; and a linear gradient from $50 \%$ to $100 \%$ B in $20 \mathrm{~min}$. Solvent A is $0.1 \%$ trifluoroacetic acid (TFA), and solvent $\mathrm{B}$ is $70 \%$ acetonitrile with $0.06 \%$ TFA. Before injection the sample was clarified by centrifugation and acidified by the addition of $10 \mu \mathrm{l}$ of $10 \%$ TFA. Peptide absorbance was monitored at $215 \mathrm{~nm}$, and $100-\mu \mathrm{l}$ fractions were collected throughout the run. Typically, major peptide peaks eluted at $25-45 \%$ B. Peak fractions were sequenced directly without concentration on an Applied Biosystems model 475 automated sequencer with an on-line $120 \mathrm{~A}$ HPLC PTH analyzer. Typical initial yields for the amino acid sequencer were in the range of 5-25 pmoles.

\section{Cloning the RFA genes}

RFA1 The amino acid sequence of peptide VLEQPDGTWR was used to design the 64-fold degenerate 21-mer oligonucleotide RFAl-1 (5'-GARCA RCCWG AYGGW ACWTG G-3'). Abbreviations: (R) A/G; (W) A/T; (Y) C/T; (N) A/C/G/T; (D) $\mathrm{A} / \mathrm{G} / \mathrm{T}$. Oligonucleotide RFAl-1 hybridized strongly to a single 5.3-kb EcoRI band on low-stringency Southern blots (final wash, $46^{\circ} \mathrm{C} / 6 \times \mathrm{SSC} / 0.1 \%$ SDS). This $5.3-\mathrm{kb}$ EcoRI band was obtained from a size-selected genomic EcoRI plasmid library in pBluescript SK - (plasmid pJM101). DNA sequencing revealed an ORF, containing an amino acid sequence corresponding to that of the original peptide. However, the ORF continued past the EcoRI site. A large (13.3-kb) DNA fragment containing RFA1 was identified by using the insert to pIM101 to screen a HindIII partial genomic plasmid library constructed from strain SP-1 (provided by $M$. Wigler). Extensive restriction mapping and sequencing localized the RFA1 gene to a $2.6-\mathrm{kb}$ PstI-HindIII fragment. This fragment was isolated from a size-selected PstIHindIII genomic library from strain W303-1a in SK + (pJM112) and used as template for DNA sequencing. All DNA sequencing was performed with Sequenase (U.S. Biochemical). Directional deletions were made with exonuclease and S1 nuclease.

RFA2 PCR primers were designed by using sequence information from each end of a single long peptide, KWSEDANDLAAGNDDSSGK, that was obtained by amino acid sequencing. The advantage of the use of PCR within a single peptide is that the size of the correct PCR product can be predicted precisely.
The use of the 128-fold degenerate 28-mer oligonucleotide, 361W1 (5'-ATCTC GAGAA RTGGT CNGAR GAYGC NAA-3'), and the 512-fold degenerate 29-mer oligonucleotide, 36-1Cl $\left(5^{\prime}\right.$ TAGGA TCCYT TWCCN GANGA RTCRT CRTT-3'।, predicted a 73-bp product following amplification of genomic DNA. All PCR reactions were performed under the following conditions: $50-\mu l$ reaction volume containing 100 pmoles of each primer, 2.5 units of AmpliTaq (Perkin-Elmer) polymerase, and buffer conditions according to the manufacturer. The PCR reaction $\left(95^{\circ} \mathrm{C}\right.$ for $30 \mathrm{sec} / 45^{\circ} \mathrm{C}$ for $1 \mathrm{~min} / 65^{\circ} \mathrm{C}$ for $1 \mathrm{~min} / 30$ cycles) was carried out on $25 \mathrm{ng}$ of yeast DNA and resulted in two major bands, one of which was $\sim 73 \mathrm{bp}$ as judged by an $8 \%$ PAGE gel. This band was eluted from the gel. Following digestion with $X h o I$ and BamHI, the fragment was cloned and sequenced and found to contain an ORF with the same internal amino acid sequence as that of the original peptide. When the 73-bp band was used as a probe on Southern blots, it detected a single $3.8-\mathrm{kb}$ EcoRI band (final wash, $55^{\circ} \mathrm{C} / 0.5 \times \mathrm{SSC} / 0.1 \%$ SDS). This fragment was obtained from a size-selected genomic EcoRI plasmid library (pIM201) and found to contain a large ORF with matches to additional peptide sequences. However, the ORF again extended past the EcoRI site. Further Southern blotting revealed that the ORF was contained on a $5.2-\mathrm{kb}$ HindIII fragment. This fragment was isolated from a size-selected genomic HindIII plasmid library (pJM205) and found to contain the entire RFA2 gene within the PstI and XmnI sites.

RFA2 cDNA Fifteen micrograms of total yeast nucleic acid, isolated as described (Brill and Sternglanz 1988), was reversetranscribed in a $75-\mu \mathrm{l}$ reaction containing $0.1 \mathrm{mg} / \mathrm{ml}$ of random hexamer primers (Pharmacia), $1 \times \mathrm{RT}$ buffer (BRL), $0.5 \mathrm{~mm}$ dNTPs, 60 units of RNasin (Promega), and 400 units of Moloney murine leukemia virus (MoMLV) reverse transcriptase (BRL). The reaction proceeded for $60 \mathrm{~min}$ at $37^{\circ} \mathrm{C}$ before the nucleic acids were precipitated by the addition of $225 \mu \mathrm{l}$ of TE, $1 \mu \mathrm{g}$ of tRNA, $100 \mu \mathrm{l}$ of $2.3 \mathrm{M} \mathrm{NaClO}_{4}$, and $200 \mu \mathrm{l}$ of isopropanol. The precipitate was centrifuged for $15 \mathrm{~min}$, washed with $70 \%$ ethanol, dried, and resuspended in $50 \mu \mathrm{l}$ of TE. Ten microliters of the first-strand reaction products were subjected to PCR $\left(94^{\circ} \mathrm{C}\right.$ for $0.5 \mathrm{~min} / 50^{\circ} \mathrm{C}$ for $1 \mathrm{~min} / 72^{\circ} \mathrm{C}$ for $1 \mathrm{~min} / 30$ cycles) by using as primers the 21-mer oligonucleotide, RFA2-1 (5'-CTATC TAGAA CAGGC TAGTT T-3'), and the 24-mer oligonucleotide, RFA2-2 (5'-GACTC TAGAA TTTGT TTGAT CGTC-3'). The products from this reaction, 183- and 291-bp fragments, were isolated from a 5\% PAGE gel, digested with $X b a \mathrm{I}$, and subcloned into pSK + (pIM220 and pIM221, respectively). Plasmid pJM214 contains the $1.2-\mathrm{kb}$ ClaI-XmnI fragment of RFA2 ligated into the ClaI and EcoRV sites of pSK + in which the genomic $X b a I$ fragment is replaced by the cDNA $X b a I$ fragment from pJM220.

RFA3 PCR primers were designed by using sequence information from each end of a single long peptide, SQPTESQLILQSPTISWK, that was obtained by amino acid sequencing. The $\mathrm{W}$ at position 17 was in error and resulted in a single mismatch in the corresponding oligonucleotide. The use of the 256fold degenerate 28-mer oligonucleotide, 13-4W (5'-TAGGA TCCCA RCCWA CWGAR TCNCA RYT-3'), and the 96-fold degenerate 26-mer oligonucleotide, 13-5C $\left(5^{\prime}\right.$-ATCTC GAGYT TCCAN GADAT WGTWG G-3'), predicted a 67-bp product following amplification of genomic DNA. The PCR reaction $\left(94^{\circ} \mathrm{C}\right.$ for $1.5 \mathrm{~min} / 45^{\circ} \mathrm{C}$ for $1.5 \mathrm{~min} / 72^{\circ} \mathrm{C}$ for $1 \mathrm{~min} / 30$ cycles) was carried out on $10 \mathrm{ng}$ of yeast DNA and resulted in three major bands, one of which was $\sim 67$ bp as judged by an $8 \%$ PAGE gel. This band was eluted from the gel. Following digestion with $X h o I$ and BamHI, the fragment was cloned and se- 
quenced and found to contain an ORF with the same internal amino acid sequence as that of the original peptide. When the 67-bp band was used as a probe on Southern blots it detected a single $7-\mathrm{kb} E c 0$ RI band (final wash, $55^{\circ} \mathrm{C} / 0.1 \times \mathrm{SSC} / 0.1 \% \mathrm{SDS}$ ). This fragment was obtained from a size-selected genomic EcoRI plasmid library (pIM301), and the region of hybridization narrowed to a $1.0-\mathrm{kb}$ HindIII fragment. Sequence of this region revealed an ORF with matches to additional peptide sequences. The complete gene was found to be contained on a PvuII-EcoRV fragment (pIM318).

\section{Physical mapping}

A set of DNAs on nylon filters from $\sim 1000$ overlapping yeast clones in phage $\lambda$ was provided by Linda Riles and Maynard Olson (Washington University, St. Louis). Random hexamerlabeled probes were made from the fragments shown in Figure 2. The RFA1 probe detected $\lambda$ clones 4236 and 4239, the RFA2 probe detected $\lambda$ clones 5413 and 6742 , and the RFA3 probe detected $\lambda$ clone 6699 .

\section{Plasmid constructions}

Plasmids pJM118, pJM223, and pJM329 contain, respectively, the RFA1, RFA2, and RFA3 genes or CDNA under the control of the phage $\mathrm{T} 7$ promoter and are described below. Plasmid pJM106, which contains the 2.6-kb PstI-HindII fragment of RFA1 cloned into the polylinker of pVT102L (Vernet et al. 1987), was digested with MluI and subjected to Bal31 exonuclease, XhoI digestion, Klenow flushing, and self-ligation. The plasmid pJM106 $\Delta 10$ was recovered, in which nucleotide number 450 of RFA1 is fused to the polylinker of pVT102L. The 1.9-kb XbaI-ScaI fragment of pIM106 10 was ligated into the NheI site and the filled-in BamHI site of pET1la /Studier et al. 1990) to create pJMI18. The protein encoded by this construction replaces the first 4 amino acids of RFA1 with the amino acids MARRAPR encoded by the polylinker.

Plasmid pJM214 $(0.2 \mu \mathrm{g})$ containing the RFA2 cDNA, was used as template for PCR using as primers the 22-mer oligonucleotide, RFA2T7-1 (5'-ATGCA TATGG CAACC TATCA AC$\left.3^{\prime}\right)$, and the reverse sequencing primer $\left(5^{\prime}\right.$-AACAG CTATG ACCAT G-3 $)$. Following PCR $\left(94^{\circ} \mathrm{C}\right.$ for $0.5 \mathrm{~min} / 50^{\circ} \mathrm{C}$ for $1 \mathrm{~min} /$ $72^{\circ} \mathrm{C}$ for $2 \mathrm{~min} / 10 \mathrm{cycles} /$, the $1.1-\mathrm{kb}$ product was digested with $\mathrm{NdeI}$ and BamHI and ligated into the NdeI and BamHI sites of pET1la to create pJM223.

Plasmid pJM318 $(0.2 \mu \mathrm{g})$ was used as template for PCR by using as primers the 22-mer oligonucleotide, RFA3T7-1 $\mid 5^{\prime}$-ATGCA TATGG CCAGC GAAAC AC- $\left.3^{\prime}\right)$, and the reverse sequencing primer $\left(5^{\prime}\right.$-AACAG CTATG ACCAT G-3'). Under the conditions described above, a $0.73-\mathrm{kb}$ product was obtained, digested with NdeI and BamHI, and ligated into the NdeI and BamHI sites of pET11a to create pIM329.

Plasmids pIM111, pJM211, and pJM317 contain the alleles rfa1::TRP1, Ifa2::TRP1, and rfa3::TRP1, respectively, and are described below. Plasmid pJM111 contains the 5.1 -kb XhoIBamHI fragment of RFA1 in $\mathrm{pSK}$ - in which the $1.45-\mathrm{kb}$ EcoRV-EcoRI fragment is replaced by the $0.83-\mathrm{kb}$ EcoRI-StuI fragment of TRP1. The allele was transplaced by transformation of $2.5 \mu \mathrm{g}$ of pIM111 DNA following XhoI-BamHI digestion. Plasmid pIM 211 is the $4.4-\mathrm{kb}$ SacI of RFA2 cloned into pSK + in which the $530-\mathrm{bp} H p a \mathrm{I}-E \mathrm{C} O \mathrm{RI}$ is replaced by the $0.83-\mathrm{kb}$ EcoRIStuI of TRP1. The allele was transplaced by transformation of $2.5 \mu \mathrm{g}$ of pJM211 DNA following SacI digestion. Plasmid pIM317 was constructed by replacing the $0.3-\mathrm{kb}$ MscI-HindIII of pIM301 with the $0.83-\mathrm{kb} T R P 1$ gene on a SmaI-HindIII fragment. The allele was transplaced by transformation of $2.5 \mu \mathrm{g}$ of
pIM317 DNA following EcoRI digestion. All disruptions were verified by Southern blotting.

Plasmids pIM217 and pIM403 are galactose expression plasmids. Plasmid pIM217 contains the 1.1-kb Sall-BamHI fragment of pJM214 cloned into the SalI and BamHI sites of YEp51. Plasmid pIM403 was constructed by moving the EcoRI fragment of the human RP-A $32-\mathrm{kD}$ subunit $(\mathrm{pLE} 1$; Erdile et al. 1990 ) into YEp51 on a SalI-BamHI fragment.

\section{Bacterial expression}

The vector plasmid pET11a and the recombinant plasmids pJM118, pJM223, and pIM329 were transformed into bacterial strain BL21(DE3) in which T7 RNA polymerase is under the control of the lacUV5 promoter (Studier et al. 1990). When the cultures reached an $\mathrm{OD}_{600}$ of 0.6 the cells were induced by the addition of IPTG to $0.4 \mathrm{~mm}$ for $2 \mathrm{hr}$, pelleted, and resuspended in one-tenth volume of TE. An equal volume of $2 \times$ SDS-PAGE sample buffer was quickly added, and the sample was heated at $100^{\circ} \mathrm{C}$ for $5 \mathrm{~min}$. Samples were sonicated for $20 \mathrm{sec}$ to shear chromosomal DNA and $5 \mu \mathrm{l}(\sim 10 \mu \mathrm{g}$ of protein, RFA1, and $R F A 3)$ or $1 \mu \mathrm{l}(\sim 2 \mu \mathrm{g}$ of protein, $R F A 2)$ was subjected to electrophoresis on a $1.5-\mathrm{mm}$-thick $17 \%$ SDS-PAGE gel and transferred to nitrocellulose. As a control, $\sim 0.5 \mu \mathrm{g}$ of RF-A was run alongside each sample. The nitrocellulose was stained with Ponceau $\mathrm{S}$ to visualize the lanes that were separated and incubated with a $1: 100$ dilution of the appropriate affinity-purified rabbit antibody raised against the individual subunits of yeast RF-A. The nitrocellulose strips were washed, incubated with a $1: 1000$ dilution of ${ }^{125}$ I-labeled goat anti-rabbit (ICN) as secondary antibody, washed again, and exposed to film.

\section{Yeast cell-cycle expression}

Yeast was grown at $30^{\circ} \mathrm{C}$ in $150 \mathrm{ml}$ of YPD $(1 \%$ yeast extract, $2 \%$ peptone, $2 \%$ dextrose) to an $\mathrm{OD}_{600}$ of 1.0 and was arrested by the addition of $\alpha$-factor (Sigma) to $2.4 \mu \mathrm{M}$. After $100 \mathrm{~min}$, the cells were pelleted in a clinical centrifuge, washed once with 10 $\mathrm{ml}$ of YPD, and resuspended in $200 \mathrm{ml}$ of YPD at $30^{\circ} \mathrm{C}$. Thirteen-milliliter samples were taken every $15 \mathrm{~min}$ into $15-\mathrm{ml}$ polypropylene tubes, quickly pelleted, and frozen at $-70^{\circ} \mathrm{C}$. Simultaneously, $25 \mu \mathrm{l}$ of each aliquot was fixed with an equal volume of $3.7 \%$ formaldehyde $/ 0.15 \mathrm{M} \mathrm{NaCl}$ for microscopy. Isolation of nucleic acids and Northern analysis was performed essentially as described (Brill and Sternglanz 1988).

\section{Acknowledgments}

We thank Dan Marshak, Gil Morris, and members of the laboratory for technical advice; Georgia Binns for performing the automated peptide sequencer analysis; Steve Bell, Anindya Dutta, and Jan Mullen for comments on the manuscript; and Linda Riles and Maynard Olson for access to their yeast genomic library for physical mapping. This research was supported by a grant from the National Institutes of Health (AI20460).

The publication costs of this article were defrayed in part by payment of page charges. This article must therefore be hereby marked "advertisement" in accordance with 18 USC section 1734 solely to indicate this fact.

\section{Note added in proof}

The sequence of the gene encoding the human $70-\mathrm{kD}$ subunit has been published by Erdle et al. (J. Biol. Chem. 266: 1209012098, 1991.) 
Sequence data described in this paper have been submitted to the EMBL/GenBank Data Libraries under accession numbers X59748 (RFA1), X59749 (RFA2), and X59750 (RFA3).

\section{References}

Bauer, G.A. and P.M.J. Burgers. 1990. Molecular cloning, structure and expression of the yeast proliferating cell nuclear antigen gene. Nucleic Acids Res. 18: 261-265.

Brill, S.J. and R. Sternglanz. 1988. Transcription-dependent DNA supercoiling in yeast DNA topoisomerase mutants. Cell 54: 403-411.

Brill, S.J. and B. Stillman. 1989. Yeast replication factor-A functions in the unwinding of the SV40 origin of DNA replication. Nature 342: 92-95.

Bullock, P.A., Y.S. Seo, and J. Hurwitz. 1989. Initiation of simian virus 40 DNA replication in vitro: Pulse-chase experiments identify the first labeled species as topologically unwound. Proc. Natl. Acad. Sci. 86: 3944-3948.

Challberg, M.D. and T.J. Kelly. 1989. Animal virus DNA replication. Annu. Rev. Biochem. 58: 671-717.

Coverley, D., M.K. Kenny, M. Munn, W.D. Rupp, D.P. Lane, and R.D. Wood. 1991. Requirement for the replication protein SSB in human DNA excision repair. Nature 349: 538-541.

Dayhoff, M.O., W.C. Barker, and L.T. Hunt. 1983. Establishing homologies in protein sequences. Methods Enzymol. 91: $524-545$.

Dean, F.B., P. Bullock, Y. Murakami, C.R. Wobbe, L. Weissback, and J. Hurwitz. 1987. Simian virus 40 (SV40) DNA replication: SV40 large $T$ antigen unwinds DNA containing the SV40 origin of replication. Proc. Natl. Acad. Sci. 84: 16-20.

Din, S., S.J. Brill, M.P. Fairman, and B. Stillman. 1990. Cellcycle-regulated phosphorylation of DNA replication factor A from human and yeast cells. Genes \& Dev. 4: 968-977.

D'Urso, G., R.L. Marraccino, D.R. Marshak, and J.M. Roberts. 1990. Cell cycle control of DNA replication by a homologue from human cells of the $\mathrm{p} 34^{\mathrm{cdc} 2}$ protein kinase. Science 250: 786-791.

Erdile, L.F., M.S. Wold, and T.J. Kelly. 1990. The primary structure of the $32-\mathrm{kDa}$ subunit of human replication protein $\mathrm{A}$. J. Biol. Chem. 265: 3177-3182.

Fairman, M.P. and B. Stillman. 1988. Cellular factors required for multiple stages of SV40 replication in vitro. EMBO $)$. 7: 1211-1218.

Harris, S.D. and J.R. Pringle. 1991. Genetic analysis of Saccharomyces cerevisiae chromosome I: On the role of mutagen specificity in delimiting the set of genes identifiable using temperature-sensitive-lethal mutations. Genetics 127: 279285.

Heyer, W.-D., M.R.S. Rao, L.F. Erdile, T.J. Kelly, and R.D. Kolodner. 1990. An essential Saccharomyces cerevisiae single-stranded DNA binding protein is homologous to the large subunit of human RP-A. EMBO I. 9: 2321-2329.

Hurwitz, J., F.B. Dean, A.D. Kwong, and S.-H. Lee. 1990. The in vitro replication of DNA containing the SV40 origin. I. Biol. Chem. 265: 18043-18046.

Kenny, M.K., S.-H. Lee, and J. Hurwitz. 1989. Multiple functions of human single-stranded-DNA binding protein in simian virus 40 DNA replication: Single-strand stabilization and stimulation of DNA polymerases $\alpha$ and $\delta$. Proc. Natl. Acad. Sci. 86: 9757-9761.

Kenny, M.K., U. Schlegel, H. Furneaux, and J. Hurwitz. 1990. The role of human single stranded DNA binding protein and its individual subunits in simian virus 40 DNA replication. I. Biol. Chem. 265: 7693-7700.
Lee, S.-H., T. Eki, and J. Hurwitz. 1989. Synthesis of DNA containing the simian virus 40 origin of replication by the combined action of DNA polymerases $\alpha$ and $\delta$. Proc. Natl. Acad. Sci. 86: 7361-7365.

Li, J.J. and T.J. Kelly. 1984. Simian virus 40 DNA replication in vitro. Proc. Natl. Acad. Sci. 81: 6973-6977.

- 1985. Simian virus 40 DNA replication in vitro: Specificity of initiation and evidence for bidirectional replication. Mol. Cell. Biol. 5: 1238-1246.

Lowndes, N.F., A.L. Johnson, and L.H. Johnston. 1991. Coordination of expression of DNA synthesis genes in budding yeast by a cell-cycle regulated trans factor. Nature 350: $247-$ 250.

Matsumoto, T., T. Eki, and J. Hurwitz. 1990. Studies on the initiation and elongation reactions in the simian virus 40 DNA replication system. Proc. Natl. Acad. Sci. 87: 97129716.

Meeks-Wagner, D. and L.H. Hartwell. 1986. Normal stoichiometry of histone dimer sets is necessary for high fidelity of mitotic chromosome transmission. Cell 44: 43-52.

Melendy, T. and B. Stillman. 1991. Purification of DNA polymerase $\delta$ as an essential simian virus 40 DNA replication factor. J. Biol. Chem. 266: 1942-1949.

Memet, S., M. Gouy, C. Marck, A. Sentenac, and J.-M. Buhler. 1988. RPA190, the gene coding for the largest subunit of yeast RNA polymerase A. J. Biol. Chem. 263: 2830-2839.

Mitsui, K. and K. Tsurugi. 1988. cDNA and deduced amino acid sequence of $38 \mathrm{kDa}$-type acidic ribosomal protein $\mathrm{A} 0$ from Saccharomyces cerevisiae. Nucleic Acids Res. 16: 3573

Murakami, Y., C.R. Wobbe, L. Weissbach, F.B. Dean, and J. Hurwitz. 1986. Role of DNA polymerase $\alpha$ and DNA primase in simian virus 40 DNA replication in vitro. Proc. Natl. Acad. Sci. 83: 2869-2873.

Pizzagalli, A., P. Valsasnini, P. Plevani, and G. Lucchini. 1988. DNA polymerase I gene of Saccharomyces cerevisiae: Nucleotide sequence, mapping of a temperature-sensitive mutation, and protein homology with other DNA polymerases. Proc. Natl. Acad. Sci. 85: 3772-3776.

Prelich, G., M. Kostura, D.R. Marshak, M.B. Mathews, and B. Stillman. 1987. The cell-cycle regulated proliferating cell nuclear antigen is required for SV40 DNA replication in vitro. Nature 326: 471-475.

Riva, M., S. Memet, J.-Y. Micouin, J. Huet, I. Treich, J. Dassa, R. Young, J.-M. Buhler, A. Sentenac, and P. Fromageot. 1986. Isolation of structural genes for yeast RNA polymerases by immunological screening. Proc. Natl. Acad. Sci. 83: 1554 1558.

Roberts, J.M. and G. D'Urso. 1988. An origin unwinding activity regulates initiation of DNA replication during mammalian cell cycle. Science 241: 1486-1489.

Rothstein, R.J. 1983. One-step gene disruption in yeast. Methods Enzymol. 101: 202-211.

Stillman, B. 1989. Initiation of eukaryotic DNA replication in vitro. Annu. Rev. Cell. Biol. 5: 197-245.

Stillman, B.W. and Y. Gluzman. 1985. Replication and supercoiling of simian virus 40 DNA in cell extracts from human cells. Mol. Cell. Biol. 5: 2051-2060.

Studier, W.F., A.H. Rosenberg, J.J. Dunn, and J.W. Dubenborff. 1990. Use of T7 RNA polymerase to direct expression of cloned genes. Methods Enzymol. 185: 60-89.

Tsurimoto, T. and B. Stillman. 1989a. Purification of a cellular replication factor, RF-C, that is required for coordinated synthesis of leading and lagging strands during simian virus 40 DNA replication in vitro. Mol. Cell. Biol. 9: 609-619.

. 1989b. Multiple replication factors augment DNA synthesis by the two eukaryotic DNA polymerases, $\alpha$ and $\delta$. 
$E M B O$ J. 8: 3883-3889.

1991. Replication factors required for SV40 DNA replication in vitro. II. Switching of DNA polymerase $\alpha$ and $\delta$ during initiation of leading and lagging strand synthesis. $I$. Biol. Chem. 266: 1961-1968.

Tsurimoto, T., M.P. Fairman, and B. Stillman. 1989. Simian virus 40 DNA replication in vitro: Identification of multiple stages of initiation. Mol. Cell. Biol. 9: 3839-3849.

Tsurimoto, T., T. Melendy, and B. Stillman. 1990. Two DNA polymerase complexes sequentially initiate lagging and leading strand synthesis at the simian virus 40 origin of DNA replication. Nature 346: 534-539.

Vernet, T., D. Dignard, and D.Y. Thomas. 1987. A family of yeast expression vectors containing the phage $\mathrm{f} 1$ intergenic region. Gene 50: 225-233.

Wallis, J.W., G. Chrebet, G. Brodsky, M. Rolfe, and R. Rothstein. 1989. A hyper-recombination mutation in S. cerevisiae identifies a novel eukaryotic topoisomerase. Cell 58: $409-419$.

Weinberg, D.H. and T.J. Kelly. 1989. Requirement for two DNA polymerases in the replication of simian virus 40 DNA in vitro. Proc. Natl. Acad. Sci. 86: 9742-9746.

Weinberg, D.H., K.L. Collins, P. Simancek, A. Russo, M.S. Wold, D.M. Virshup, and T.J. Kelly. 1990. Reconstitution of simian virus 40 DNA replication with purified proteins. Proc. Natl. Acad. Sci. 87: 8692-8696.

Wobbe, C.R., F. Dean, L. Weissbach, and J. Hurwitz. 1985. In vitro replication of duplex circular DNA containing the simian virus 40 DNA origin site. Proc. Natl. Acad. Sci. 82: $5710-5714$.

Wobbe, C.R., L. Weissbach, J.A. Borowiec, F.B. Dean, Y. Murakami, P. Bullock, and J. Hurwitz. 1987. Replication of simian virus 40 origin-containing DNA in vitro with purified proteins. Proc. Natl. Acad. Sci. 84: 1834-1838.

Wold, M.S. and T.J. Kelly. 1988. Purification and characterization of replication protein $\mathrm{A}$, a cellular protein required for in vitro replication of simian virus 40 DNA. Proc. Natl. Acad. Sci. 85: 2523-2527.

Wold, M.S., J.J. Li, and T.J. Kelly. 1987. Initiation of simian virus 40 DNA replication in vitro: Large-tumor-antigen and origin-dependent unwinding of the template. Proc. Natl. Acad. Sci. 84: 3643-3647.

Wold, M.S., D.H. Weinberg, D.M. Virshup, J.J. Li, and T.J. Kelly. 1989. Identification of cellular proteins required for simian virus 40 DNA replication. J. Biol. Chem. 264: 2801-2809.

Yang, L., M.S. Wold, J.J. Li, T.J.Kelly, and L.F. Liu. 1987. Roles of DNA topoisomerases in simian virus 40 DNA replication in vitro. Proc. Natl. Acad. Sci. 84: 950-954. 